Živanka Miladinović Bogavac ${ }^{1}$

University Union "Nikola Tesla"Belgrade

Business and Law Faculty
SCIENTIFIC REVIEW ARTICLE

DOI:10.5937/ekonomika1703087M

Received: Jul, 12, 2017

Accepted: September, 09, 2017

\title{
NATIONAL MINORITIES, WITH SPECIAL OPENING OPINION IN THE REPUBLIC OF SERBIA
}

\begin{abstract}
The term national minority emerged in the modern age at international conferences. They gain special significance by forming the first international universal organization, the Society of Nations. In Serbia, the issue of the position of minorities appears after gaining independence in 1878. After the Second World War, the existence and position of a minority is determined by new international conventions. Concerning the SFRY, the protection of minorities was guaranteed by the constitution. Serbia and other countries that emerged from the breakup of the SFRY regulated this issue by laws and bilateral agreements. Serbia has bilateral agreements on the protection of minorities from several neighboring countries. The position of minorities in Serbia can be assessed as exceptionally good, which can not be said about the position of the Serb minority in some neighboring countries.
\end{abstract}

Key words: National minority, protection, constitution, state, agreement

JEL Classification: K38, K39

\section{НАЦИОНАЛНЕ МАЊИНЕ, СА ПОСЕБНИМ ОСВРТОМ НА ПОЛОЖАЈ МАЫИНА У РЕПУБЛИЦИ СРБИЈИ}

\begin{abstract}
Апстракт
Појам национална мањина настао је у новом веку на међународним конферениијама. Посебан значај добијају формирањем прве међународне универзалне организације, Друштва народа. У Србији се питање положаја мањина појављује после добијања независности 1878. године. После Другог светског рата постојање и положај мањине се утврђује новим међународним конвениијама. Што се тиче СФРЈ заштита мањина је била загарантована уставом. Србија као и остале државе које су настале распадом СФРЈ ово питање уређују законима и билатералним споразумима. Србија има билатералне споразуме о заштити манина са неколико суседних држава. Положај мањина у Србији се може оценити као изузетно добар, ито се не може рећи за положај српске мањине у неким суседним државама.
\end{abstract}

Кључне речи: наџионална мањина, заштита, устав, држава, споразум

\footnotetext{
${ }^{1}$ zivankamiladinovic@gmail.com.
} 


\section{Introduction}

The system of minority protection in the Republic of Serbia was developed even during the Socialist Federal Republic of Yugoslavia, in which, in a different way to the other socialist countries, the question of nations and entities was looked at, while the Eastern Bloc countries did not specifically address the issue, nor did they develop a system of protection Ethno-cultural groups.

Ethno-cultural groups. The SFR Yugoslavia, through various mechanisms, secured the protection of the rights of the so-called "nationalities". The 1974 Constitution defined the status of national minorities and their collective rights. The Yugoslav "key" institution enabled, despite the one-party system, the representation of minorities in political life. Through the "key" all SFR Yugoslavia national groups, in which there were 6 constituent peoples, were proportionally represented at all levels of government. The highest level of participation was, as it is today, at the local level. Within the SFR Yugoslavia, members of minority groups had the right to official use of languages, autonomy in culture in terms of establishing different cultural associations and cultural institutions, as well as education in their mother tongue. At that time, the majority of members of minority ethnic and cultural groups lived in the territory of the Republic of Serbia. Following the change of power in the 2000 elections, the new government in Serbia took the necessary measures to join the United Nations, the Council of Europe and other international organizations, as well as obligations related to international standards for the protection of national minorities. This meant that the state committed itself to developing democratic institutions and procedures and adopting special measures aimed at the protection of national minorities, thus implementing a multicultural policy recommended through the documents of the OSCE, the Council of Europe, the European Commission, etc. Among the most important documents Serbia is a Framework Convention for the Protection of National Minorities Rights and the European Charter of Regional and Minority Languages, which defines the minimum protection guaranteed to minority groups. Today, the position of minorities is regulated by special laws, among which the Law on the Protection of the Rights and Freedoms of National Minorities, the Law on the Official Use of Languages and Letters, the Law on the Foundations of the Education System and the Law on Local Self-Government. Apart from this, Serbia has bilateral agreements on the protection of national minorities with Croatia, Macedonia, Hungary and Romania.

\section{Definition and notion of minorities}

The affiliation of a minority can be appreciated on the basis of subjective elements, that is, the statement of a person about belonging to a particular minority or on the basis of objective elements, ie the existence of certain facts which objectively determine the affiliation of one person to a particular minority population (Avramov and Kreća, 1997, p. 276).

There are different definitions of minority concepts. Perhaps the most precise definition is given by Francesco Capotorti. He says that the minority by number of members of the population is smaller than the rest of the population and has special cultural characteristics (especially language, religion, etc.). We can call this an objective 
element of the definition of a minority. The subjective element of this definition is related to the pronounced mutual solidarity of the population that refers to the preservation of its identity (Marković, 2004, p. 479).

The definition of a national minority is also given in an international act (an additional protocol to the Convention on the Protection of Human Rights and Freedoms Relating to Persons belonging to National Minorities of 1993). The definition determines that a minority is made up of a group of people who live in the territory of one state for a long period, with which there are long-term relationships, that is, its citizens and that members of the minority have some cultural, religious and linguistic specifics in relation to the majority population.

From these definitions we can conclude that the national minority is a part of the population of the state (that is, its citizens), which differs from the majority population according to the characteristics inherent in their nation. Members of national minorities are provided, in addition to universal human rights, and special rights whose purpose is to preserve their national identity of identity (Marković, 2004, p. 481). National minorities do not have the right to a special territory. There is no international instrument guaranteeing minorities the right to political or territorial autonomy. Hence minorities, as a collectivity, have not been granted the right to self-determination until secession. Selfdetermination, which is enshrined in the human rights pact, has an individual character, but it does not have a collective character. It implies a free commitment in the religious, national, ideological and linguistic sense of every human being and even of the minority.

Affiliation to a national minority must not, in any case, arise through ancestor or family affiliation, but may be a result of upbringing, or a subjective subject matter.

\section{National and ethnic minorities}

The division into national and ethnic minorities was made in relation to the existence, or non-existence of, the mother nation. This division also has to do with the existence of the home state of one nation. This means that a national minority is understood to mean that the population living in the territory of the national state of another nation, and has its own national state (Marković, 2004, p. 481).

When we talk about an ethnic group, the essence lies in the absence of a home state. This population has awareness of its identity (cultural, language, traditional), which is different from that of the majority nation in that country. What should be especially emphasized when it comes to minorities is the will of the minority to show its particularity. This particularity refers to the parent majority nation in a given state (Marković, 2004, p. 481).

What is important for determining the existence of a national minority, or for the existence of minority rights, is the existence of certain characteristics. This is the first determination of which group of people has the status of a national minority, what are the particularities that should be protected by the appropriate legal norms and ultimately determine the mechanisms for the revival of minority rights (Marković, 2004, p. 481). 


\section{Minorities in the Republic of Serbia}

The relationship of the majority and minority in Serbia is based on several stereotypes. The first is the stereotype that most have the automatic right to rule, and that this right will automatically be abolished if minorities are given the rights. This construction is very important because rights (including basic human rights) in this kind of thinking are considered as something that is given to or given to someone. The second stereotype is based on the belief that minorities are culturally, intellectually and emotionally inferior to the majority. This kind of thinking is especially evident when it comes to gender equality (Nikolić, 2005).

This is also the third stereotype - that is, in the political fight against the representatives of minority opinion, all means are allowed. Political struggle is understood here as a struggle for life or death, war to extermination, and here there is a continuity of Serbian parliamentarism, which according to historians can be traced back to the end of the 19th century. From this attitude towards political opponents (where obviously all the funds are allowed), it is completely clear that members of ethnic or religious minorities can not hope for anything better.

There is a drastic difference in the scope and quality of exercising minority rights between Vojvodina and the rest of Serbia. The multi-ethnic tradition in the institutional and legislative regulation of the rights of national minorities in Vojvodina is the basis of today's, minority-sensitive and effective behavior of the Vojvodina authorities as well as the more active attitude of the Vojvodina minorities to the issues of preserving one's own identity. The application of the law greatly complicates the aforementioned legal conflict, inconsistencies and non-existence of certain legal solutions.

The economic conditions in which they exist are of special importance for the position of national minorities. The economic frameworks in which one national minority exists depends on several factors. This may be the level of development of the entire state or the minority's minority. Similarly, financial investments in areas where minorities live may also be the basis of their privileged position vis-à-vis the population in other parts of the country. Here we can mention that even financial investment in the AP Kosovo and Metohija was abused to buy the real estate of Serbs in this province and their emigration. In the end, it should be mentioned that the proximity of important international roads is of great importance, which can also influence the improvement of the position of both the minority and the population of the home country.

\section{Legal regulation of the position of national minorities in Serbia}

The position of national minorities in Serbia is probably among the best in the world. Members of national minorities have a constitutional right to political association, establishment of cultural institutions, education and information in their mother tongue, the right to choose and to be elected to local and republic authorities, to engage in economic affairs and other activities. National minorities have material conditions for their development. Vojvodina, where the most members of different nations live, is a very economically developed region, while Kosovo and Metohija, where the Albanian 
population is concentrated, although economically underdeveloped, has been developing faster than other parts of Serbia in recent years. However, Albanians in Kosovo and Metohija do not recognize the Republic of Serbia in which they live, nor its constitution. Under the pressure of separatist national leaders and with the external support of certain world powers, the Albanian minority boycotts all state institutions through which they should exercise their rights and freedoms. They do not recognize state authorities, refuse to pay taxes, they do not allow their children to study in Serbian in public schools according to programs that apply to all other students in Serbia. Albanians in central Serbia often boycott democratic elections in which they could elect their legitimate representatives to local and republic authorities.

In Kosovo and Metohija, extreme and aggressive Albanian nationalism is at work, accompanied by a demographic explosion, which has changed the structure of the population in our southern province. This development was also contributed by the fact that in 1945, with Tito's approval, between 300,000 and 400,000 refugees from Albania moved to Kosovo and Metohija (Radulović, 1990). In this way, the ethnic composition of Kosovo and Metohija has changed and conditions have been created for the Albanians, which enable them, in violation of all possible international legal acts, to appear on the international political scene with the request "Kosovo Republic" (Nikolić, 2005). The Serbian people in Kosovo and Metohija are under great pressure from the beginning of the Second World War in our region (the beginning of the war was caused by the shooting of March 27, 1941, initiated by the British intelligence service) (Jerotijević and Purić, 2013, p. 116).

For the exercise of the right to cultivate the culture and traditions of national minorities, the provisions of the Law on the Protection of the Rights and Freedoms of National Minorities, which are guaranteed to them individual and collective rights, are of paramount importance. In order to exercise the right to self-government in the field of culture, education, information and official use of languages and scripts, members of national minorities can choose national councils, which are actively involved in the process of functioning of the Ministry of Culture.

\section{Legislative framework}

The basic rights of national minorities are guaranteed by the constitution and laws. These are: the right to education, the preservation and development of culture, the right to the official use of languages and letters, and the right to information in their mother language. The most important documents of our legislation relevant for the protection of national minorities are the Constitution of the Republic of Serbia, the Statute of the Autonomous Province of Vojvodina, the Law on the Protection of the Rights and Freedoms of National Minorities, a number of laws of the Republic of Serbia, decisions of provincial bodies and statutes and decisions of local self-government bodies.

The Constitution of the Republic of Serbia (adopted in 2006) defines Serbia as a state of the Serbian people and all citizens living there. In the special section entitled "Rights of Members of National Minorities", minority rights are guaranteed, both individual and collective. Article 75 provides for the creation of councils of national minorities for the purpose of exercising the right to self-government in culture, education, 
information and the official use of languages and scripts. Also, Article 20 stipulates that the achieved level of minority rights can not be reduced.

The existing Minority Protection Act of 2002 was transferred from the legislation of the former federal state of FRY. In this regard, it must be emphasized that at the level of Serbia since the year 2000, no systemic law on minorities has been adopted, some decisions are made ad hoc and regulations urgent. The Minority Protection Act does not provide for penal provisions for non-enforcement of the law, so the issue of obligation and responsibility for its implementation is raised, and in this connection the issue of a serious approach of the lawyer to this issue. The Minority Protection Act gives very high powers to national councils in the field of protection and realization of minority rights. So far, 14 national councils have been constituted as key bodies of minority selfgovernment. They should be partners of the state in the process of decision-making relevant to the exercise of minority rights, but since their powers are not clearly specified and embedded in regulations at the republic level, this is often not the case. Under Article 19 of the Minority Protection Act, state authorities are required to request an opinion and to consult with national councils when deciding on all issues concerning minority rights guaranteed by the Constitution. In practice, this legal provision is rarely and selectively applied.

The important consequences in the field of exercising minority rights include a number of special laws: the Law on the Official Use of Languages and Letters, the Law on Local Self-Government, the Law on Determining the Autonomous Province Autonomy (Omnibus Law), the Law on Public Information, the Law on the Election of Deputies and the second. It is important to note that the adoption of these laws, which are important for the exercise of a minority right, has been carried out without proper public debate in a non-transparent manner and without the participation of representatives of minorities. In addition, the field of legal regulation of minority rights is characterized by a lack of coherence, a direct conflict between the existing laws or legal solutions, the absence of certain laws and numerous by-laws. Thus, the Law on Local Self-Government does not allow the public use of national symbols of national minorities, but only the state signs and signs of local self-governments, which is in direct contradiction with the provision from the Minority Protection Act. There is also a conflict between the Law on Official Use of Languages and Letters and the provisions of the Minority Protection Act, as well as the relevant decisions of the Assembly of the AP Vojvodina. It is very important that before legal regulation of the work of national councils, especially the way of their choice, competence, and the way of financing. Existing advice currently has no legal basis for its work and operation.

\section{The right to official use of the language}

According to the existing legal solutions, the language and the letter of the members of the national minority are introduced for official use in the local self-government unit, where according to the results of the official census, more than $15 \%$ of minorities live (Law on the Protection of the Rights and Freedoms of National Minorities, Article 11). According to the principle of acquired rights, there is an obligation to retain the language and the letter in official use and in local self-government units in which the language and 
letter of the national minority were in official use at the time of enactment of the Minority Protection Act. There is the possibility of introducing languages and letters in official use in settlements or local communities if $25 \%$ or more of the national minority lives in them. In Vojvodina, in addition to the Serbian language, Hungarian, Slovak, Romanian, Croatian and Ruthenian languages are also in official use. One or more national minority languages are in official use in 38 out of 45 Vojvodina municipalities.

Field research shows that disregard of regulations in terms of enabling the official use of languages and letters for members of national minorities is very widespread. This applies to the use of languages in local self-government and state administration bodies, courts and police, even in those municipalities where minority populations have a high share in the total population of the local community.

It is not known that a legal provision has been applied according to which a person who refuses or confines a citizen to use the language or letter he serves in exercising his rights will be punished by imprisonment for up to one year (Criminal Code, Article 129).

\section{The right to education in the mother language}

The Law on the Protection of Minorities (Articles 13 and 14) regulates education in the language of national minorities. This right in Serbia is realized by members of all numerically significant minorities, besides Vlach.

In the Autonomous Province of Vojvodina, members of the Hungarian minority can be educated in their own language in 78 primary and 30 secondary schools, and in most of them, the classes are bilingual. Education in the Hungarian language covers over $77 \%$ of students from this community over the years at primary level and over $65 \%$ in secondary school. Teaching in Hungarian is also conducted at three higher schools, Hungarian language and literature departments in Belgrade and Novi Sad, and at three other universities in Vojvodina.

The situation in the education of members of other national minorities in Vojvodina is slightly less favorable: about $73 \%$ of Slovaks attend primary school and about $20 \%$ in secondary schools; About 57\% of Romanians attend elementary school in their mother language, and about $27 \%$ in secondary school. Teaching in the Croatian language takes place in 4 primary schools in the Subotica municipality, and up to now more than 200 students attend the first four grades at elementary level. The aforementioned minorities, besides Croats, also have chairs for language and literature at the Faculty of Philosophy in Novi Sad, and Slovaks and Romanians can educate teachers in their own language.

Out of Vojvodina, education in non-Serb language exists in Presevo and Bujanovac (Albanian), and somewhat in Bosilegrad (Bulgarian). This education depends on the wishes of the minorities themselves (for example, in Dimitrovgrad, the vast majority of parents decided to teach in the Serbian language). In the territory of central Serbia, students were provided with mostly optional classes of subjects of native language with elements of national culture, for members of the Bulgarian minority in two municipalities and Bosniak minorities in three municipalities. Lately, Bosnian language appeared, which extends a part of the Bosniak minority, which does not differ from the Serbian language in the local environment. 
The legal solution according to which education in the language of the national minority does not exclude the obligatory learning of the Serbian language, often because of a poor curriculum leads to the fact that members of minority communities sometimes do not speak well Serbian language.

\section{The right to participate in public life and equality in employment in the public service}

The Law on the Protection of Minorities (Article 21) stipulates that in the course of employment in public services, including the police, account is taken of the national composition of the population, the appropriate representation and knowledge of the language spoken in the area of the body or service (Law on the Protection of the Rights and Freedoms of National Minorities, Article 21). This right, however, has not been adequately transferred to the legislation of the Republic of Serbia. Amendments to the Law on the Election of Deputies from 2004 abolished the election census of 5\% of votes for political parties of national minorities. This solution, however, is useful only for members of the Hungarian and Bosniak minorities, but not numerically smaller, since, according to him, they can not cross a new realistic census. By the decision of the non-legislative body of the Republic Electoral Commission, the number of signatures necessary for the surrender of the electoral list has been reduced for national minority parties.

\section{Conclusion}

Minor protections, or the attempts to establish it, have lasted for quite some time. Some theorists consider that the first manifestation forms of this protection are created during the time of religious wars in Europe in the 17th century. From the Westphalian Peace in 1648 to the formation of the Society of Nations in 1919, there was a significant development of minority rights. For the first time in history, the Peoples' Union has created a comprehensive minority protection system. This was the basis of building the protection of minority rights in the last hundred years. The most significant United Nations act on the protection of minorities is the Covenant on Civil and Political Rights.

In my opinion, national minorities should not be allowed to claim territorial autonomy, especially if this is not in accordance with the constitution of a country. Despite the different opinions about respecting the rights of national minorities, I think that she is very respectable in our country, even to the point of respect, that it seems to me that the majority of the people have fewer rights than the minority. Our country should set a clear state strategy towards minorities. Serbia should find optimum and functional models for regulating the relations of the majority and the minority, not only because of the political stability of the country, but also for the reasons that it requires a fair organization of the society and the state.

National minorities should respect the sovereignty and national integrity of the Republic of Serbia, as it respects and guarantees their rights. At the root, any separatist ideas must be prevented and given that any kind of separatism will be punished. 


\section{References}

Avramov, S. i Kreća, M.(1997)Međunarodnojavnopravo, SavremenaAdministaracija, Beograd.

Dimitrijević, V. Račić, O. Đerić, V. Papić, T. Petrović, V. i Obradović, S. (2005) Osnovi međunarodnog javnog prava, Beogradski centar za ljudska prava, Beograd.

Đorđević, S. (2007) Uvod u međunarodno javno pravo, Pravni fakultet, Beograd.

Zakon o zaštiti prava i sloboda nacionalnih manjina, (,Sl. List SRJ“, br. 11/2002, „Sl. List SCG“, br. 1/2003 - Ustavna povelja i „Sl. Glasnik RS“ br. 72/2009 - dr. Zakon i 97/2013 - odluka US).

Janković, B. (1981) Međunarodno javno pravo, Naučna Knjiga, Beograd.

Jerotijević, Z. i Pzrić, S. (2013) Ustavnopravni razvoj Kraljevine SHS i Kraljevine Jugoslavije 1918-1941 sa posebnim osvrtom na formiranje Banovine Hrvatske, u časopis Ekonomika, br. 2/13, Niš.

Košutić, B. (2010) Osnovi prava Evropske Unije, Pravni fakultet, Beograd.

Kreća, M. (2010) Međunarodno javno pravo, Pravni fakultet, Beograd.

Krivični zakonik, (,Sl. Glasnik RS“, br. 85/2005, 88/2005 - ispr, 107/2005 - ispr, 72/2009, 11/2009, 121/2012, 104/2013, 108/2014, 94/2016).

Marković, R. (2004) Ustavno pravo, IP Justinijan, Beograd.

Marković, R. (2008) Ustavno pravo, Pravni fakultet, Beograd.

Nikolić, M. (2005) Obrazovanje i nacionalne manjine u Srbiji-problemi i izazovi, Centar za proučavanje alternativa, Beograd.

Radulović, N. (1990) Ljudska prava i nacionalne manjine u međunarodnom javnom pravu izaštitajugoslovenske manjine u Albaniji, Zbornik radiva sa međunarodnog naučnog skupa održanog na Cetinju 21, 22. i 23. juna 1990.

Šahović, M. (2008) Međunarodno pravo u međunarodnim odnosima, Službeni glasnik, Beograd. 